\title{
Social capital and development of an enterprise
}

Ph.D. Joanna Wyrwa University of Zielona Góra

\section{Introduction}

Modern economic conditions are characterized by significant dynamics and high level of insecurity, thus causing social capital to acquire particular relevance. The interest of enterprises in the concept of social capital is an expression of growing acknowledgement of its positive influence on shaping of the competitive edge of enterprises and the growth of their competitiveness. An important example is the report "Poland 2030. Developmental Challenges" (Boni 2009), which treats the growth of social capital in Poland as a challenge in itself, but also from the perspective of meeting all the remaining challenges indicated in the report. The final recommendations of the report state that: in the 2030 perspective there is a discernible threat related to a low level of social capital in Poland. This may negatively influence the factors necessary to create conditions conducive to economic growth, modernization and construction of long term competitiveness in the world (Kancelaria Prezesa Rady Ministrów 2009, p. 339). Additionally, one of the horizontal principles specified in the "Innovativeness and Efficiency Strategy of the Economy. Dynamic Poland 2020" 
(Ministerstwo Gospodarki 2013), entitled. "Partnership and cooperation" stipulates that: "Appropriate level of social capital constitutes a condition for cooperation based on trust and is a starting point for the development of modern economy. The conducted research, however, reveals that Polish society is still heading rather towards passive adaptation and not development and innovativeness" (Ministerstwo Gospodarki 2013, p. 32).

There is a commonly held opinion in the literature on the subject that the level of social capital in Poland is very low (Skawińska 2012; Czapiński, Panek 2013; Będzik 2012; Hausner 2010; Golinowska 2009; Wilczyński 2009; Fazlagić 2005). It needs to be stressed here that the results of the European Social Survey (Czapiński, Panek 2013, p. 286) research ranks Poland as one of the last countries in Europe from the point of view of social capital value (measured for e.g. trust to public institutions and engagement of citizens in public life).

The development of the concept of social capital constitutes a reaction to the breaking of a classic model of welfare state and a criticism of neo-classical paradigm in the economy and its inability to capture non-market related, social phenomena exerting influence on economic development. According to J.M. Buchannan (2001, pp. 27-34) the foundation of economy is created by both the allocation of rare resources between their alternative, and competing, areas of deployment but it is a voluntary exchange bringing mutual benefits, occurring through the interactions between individuals. In the so-called endogenic growth theory, initiated by P. Romer (after: Siwiński 2005, p. 735) in the 80's of the XX century (which brought a deviation from the neoclassical assumptions about the constant effects of scale and exogenous nature of technical progress), one draws attention to the fact that the pace and level of development depend not only on the level of accumulation of means of production, but what is particularly relevant, also joining productivity of those factors. Productivity is specified by external conditioning - endogenic growth factors, such as: innovative potential $(\mathrm{B}+\mathrm{R})$, including economy's absorption potential, institutional solutions (legal, social, cultural, political), infrastructure development, socio-economic development and the level of development of human and social capital. Today, social capital is considered to be a modern growth and socio-economic development factor since it increases the effectiveness of hard growth factors (Skawińska 2012; Jaźwiński 2010; Matysiak 2011; Sztaudynger 2005). Quality of social capital can decide about the competitive ability and innovativeness on micro and macroeconomic level.

The rapid development of the concept of social capital over the last 20 years results from changes in the economy, which is increasingly based on knowledge 
and ability to find and to transmit information very fast. The economy becomes netted more and more, and the aspiration to increase flexibility of the production while maintaining the highest quality forces enterprises to create networks in the economic system.

The growing number of empirical studies on social capital conducted all over the world will prove that social networks, interpersonal relations or values, such as trust, loyalty, credibility or cooperation between entities are perceived as main factors responsible for the efficiency of economic entities (Gajowiak 2012).

It is in this article that the key issues of social capital in enterprises are presented with the use of a critical review of the literature on this subject. It is a new and simultaneously very topical issue that is reflected in numerous theoretical and empirical studies published in the world literature over the last years. The aim of this article is to present the concept of social capital by taking into account the influence of this capital on functioning of an enterprise. The research problem considered in this article refers to social capital of a company. The hypothesis posed in the research process assumes that there is a relationship amongst the factors determined as elements of social capital and the development level of the given enterprise. Social capital is a determinant of development of enterprises. The analysis of the social capital impact on the company development was preceded by the presentation of the concept of social capital. It is in the article that an attempt to synthesize different research trends, important both for the development of the theory of social capital and, in particular, for the explanation of the role of social capital for business development, was taken.

\section{The concept of social capital}

The issues of social capital has been emerging in the deliberations of researchers with growing intensity over the last couple of years due to the constant search for an answer to the question of what conditions are most conducive for the society and economy to thrive best. The question appears all the more justified in the case of countries in which the observed potential related to natural and capital assets do not transfer into economic growth. We are looking for those factors, which may explain the causes of disproportions and possibilities of eliminating them. This provokes the thesis, that the economic success is also co-motivated by the so-called "soft variables", which are hard to operationalize, yet, constitute very relevant factors of both social and economic life.

Numerous publications dedicated to the category of social capital constitute examples of a new scientific research programme. Polish literature broadly 
refers to the phenomenon of social capital. The concepts of social capital are different ${ }^{1}$ - on the level of both conceptualization as well as operationalization (Marcinkowska 2012, p. 20). Numerous interpretations of this term are a direct consequence of divergent views. The concepts of social capital formulated by $\mathrm{P}$ Bourdieu, J. Coleman, R. Putam and F. Fukuyama became the most widespread and influential in literature. The differences between these attempts are broadly discusses in numerous publications, including also Polish ones

(Adamczyk 2013, pp. 11-61; Gajowiak 2012, pp. 14-25; Mularska-Kucharek 2012, pp. 14-19; Sławecki 2011, pp. 25-41; Klimowicz, Bokajło 2010, pp. 25-52; Grzanka 2009, pp. 78-88). The aspects that are frequently mentioned in definitions of social capital include: access and use of resources (especially intangible ones knowledge and competencies), division of norms and values, trust, generating particular benefits for the realization of goals. Amongst the definitions, there are distinguished the so-called hard ones - structural ones, emphasizing the relationships in social networks (J. Coleman); so-called soft ones - cognitive, focusing on values, trust and shared standards (R. Putnam) and, what is not to avoid, also mixed concepts. The table 1 summarizes the example concepts of social capital.

Table 1. Definitions of Social Capital

\begin{tabular}{c|l}
\hline Authors & \multicolumn{1}{c}{ Definitions of social capital } \\
\hline Bourdieu & $\begin{array}{l}\text { The aggregate of the actual or potential resources which are linked to the posses- } \\
\text { sion of a durable network of more or less institutionalized relationship of mutual } \\
\text { acquaintance or recognition }(1985, \mathrm{p} .248) .\end{array}$ \\
\hline Coleman & $\begin{array}{l}\text { Social capital is defined by its function. It is not a single entity, but a variety of dif- } \\
\text { ferent entities having two characteristics in common: they all consist of some aspect } \\
\text { of social structures, and they facilitate certain actions of individuals who are the } \\
\text { structure }(1990, \text { p. 302). }\end{array}$ \\
\hline Fukuyama & $\begin{array}{l}\text { Social capital is an instantiated informal norm that promotes co-operation between } \\
\text { two or more individuals (2001, p. 7). } \\
\text { Social capital can be defined simply as the existence of a certain set of informal val- } \\
\text { ues or norms shared among members of a group that permit cooperation among } \\
\text { them (1997, p. 378). }\end{array}$ \\
\hline
\end{tabular}

1 The interdisciplinary nature of the concept poses problems, while defining it - a consistent definition of social capital has not been created so far. 


\begin{tabular}{|c|c|}
\hline Putnam & $\begin{array}{l}\text { Social capital as features of social organization such as networks, norms, and social } \\
\text { trust that facilitate coordination and cooperation for mutual benefit }(1995, \text { p. 67). }\end{array}$ \\
\hline Adler, Kwon & $\begin{array}{l}\text { Social capital is the goodwill available to individuals or groups. Its source lies in the } \\
\text { structure and content of the actor's social relations. Its effects flow from fhe informa- } \\
\text { tion, influence, and solidarity it makes available to the actor }(2002, \text { p. 23). }\end{array}$ \\
\hline Knack & $\begin{array}{l}\text { The relationship between interpersonal trust, norms of cavity cooperation, and eco- } \\
\text { nomic performance, and some of the policy and other links through which these } \\
\text { dimensions of social capital may have economic effects (p. 1251). }\end{array}$ \\
\hline Lin & $\begin{array}{l}\text { Social capital may be defined as investment and use of embedded resources in so- } \\
\text { cial relations for expected returns }(1999, \text { p. 30). Social capital is conceptualized as } \\
\text { (1) quantity and/or quality of resources that actor (be it an individual or group or } \\
\text { community) can access or use through, (2) its location in a social network. The first } \\
\text { conceptualization of social capital emphasizes resources - the resources embedded } \\
\text { in social relations, or social resources. The second conceptualization emphasizes lo- } \\
\text { cations in a network or network characteristics }(2000, \text { p. } 786) \text {. }\end{array}$ \\
\hline $\begin{array}{l}\text { Nahapiet, } \\
\text { Ghoshal }\end{array}$ & $\begin{array}{l}\text { The sum of the actual and potential resources embedded within, available through, } \\
\text { and derived from the network of relationships possessed by an individual or social } \\
\text { unit. Social capital thus comprises both the network and the assets that may be mo- } \\
\text { bilized through that network }(1998, \text { p. } 243) \text {. }\end{array}$ \\
\hline Poters & $\begin{array}{l}\text { The ability of actors to secure benefits by virtue of membership in social networks or } \\
\text { other social structures }(1998, \text { p. 6). }\end{array}$ \\
\hline Woolcock & $\begin{array}{l}\text { Social capital - generally defined as the information, trust, and norms of reciprocity } \\
\text { inhering in one's social networks (1998, p. 153). }\end{array}$ \\
\hline
\end{tabular}

Source: study based on Bordieu 1985, p. 248; Coleman 1990, p. 302;

Fukuyama 2001, p. 7; Fukuyama 1997, p. 378; Putnam 1995, p. 67;

Adler, Kwon 2002, p. 23; Knack, Keefer 1997, p. 1251; Lin 2000, p. 786; Nahapiet, Ghoshal 1998, p. 243; Portes 1998, p. 6; Woolcock 1998, p. 153

P. Bourdieu (after: Grzanka 2009, pp. 78-79) defines social capital as current and potential resources associated with participation in sustainable networks of interrelations with a different formalization degree, wherein those social processes, occurring in these networks, are limited by the organization, in which they occur. Social capital as defined by P.B. Bourdieu (after: Sławecki 2011, pp. 25-26) is a sum of relationships, acquaintances and mutual recognition of power and capital mobilized by networks. It is in this sense that the individual potential associated with the possession of social capital depends on the extent of the network of connections and relations, in which the given entity participates and 
through which it gains access to certain resources. This potential can last and develop only through individually efforts undertaken to establish and maintain social relationships. The presented definition of social capital as a resource of an entity locates the concept of P. Bourdieu (after: Klimowicz, Bokajło 2010, p. 46) in opposition to theories of other researchers in this field. J. Coleman (after: Grzanka 2009 , p. 79) defines social capital as a resource of a variety of communities, which have shared social structures for facilitating operations of entities (of persons or organizations) within these structures. He asserted that the social connections, which occurred, when entities were trying to use their individual resources in the best possible way, could be treated as capital. It is according to J. Coleman (after: Działek 2011, p. 17) that the collective dimension of social capital, which is not owned by any entity but is located in the relationships amongst the entities, is important. The presence of other persons is essential for the appearance of social capital and joining or leaving the network results in the increase or decrease in social capital resources (after: Działek 2011, p. 17). The need of confidence of new participants in the network, who should feel obliged to act as their predecessors so as not to waste appearing opportunities, is the key element of this approach. In particular, social capital is based on networks and social connections, within which social processes are directed by a free will of individuals. J. Coleman (after: Grzanka 2009, p. 79) defines social capital as a public good and at the same time a set of such features of a social organization as confidence, norms and relationships amongst individuals, which increase their efficiency in collective actions, allow them achieving some goals, which could not be achieved without having this capital. Social capital is therefore a factor facilitating joint actions (Adamczyk 2013, p. 24). It fills up the social space amongst people and these are the interactions, thanks to which the connections and networks of social bonds are based on healthy cooperation foundations that are its source. Social capital serves improving the effectiveness of actions and the organization development. R. Putman (after: Grzanka 2009, p. 80) relates the concept of social capital to the total value of all social networks and principles arising in them for the provision of mutual services. According to this researcher, social capital is created by such features of social organizations as: networks, norms and the confidence level, which facilitate the coordination of activities and the cooperation in order to achieve mutual benefits (Mularska-Kucharek 2012, pp. 18-19). F. Fukuyama (after: Grzanka 2009, p. 80) defines social capital as existing unofficial norms and values shared by members of the given group, which enable the cooperation among them. The existence of social capital manifests itself the appearance of confidence, networking, friendship, and the like. F. Fukuyama (after: Grzanka 
2009 , p. 80) believes that cooperation is a prerequisite for functioning of all individuals aspiring to achieving their individual goals and it is why it should be treated as a private good. F. Fukuyama (after: Klimowicz, Bokajło 2010, pp. 50-51) perceives the development as the main function of social capital. It is important from the economic point of view above all. This function manifests itself in the fact that social capital leads to increased productivity and lowered costs of functioning of socio-economic entities.

It is in the presented definitions of social capital that it is possible to notice a different division of accents concerning the meaning of social standards/ norms on one hand and of relationships and the network on the other hand. It is for F. Fukuyama that social standards play the most important role, with the reservation however they must manifest themselves in specific human relationships. In the approach of R. Putman, both networks and standards are important, however, the emphasis is put on social relationships being a carrier of social standards. Similarly, by J. Coleman, social capital is reflected in social relationships above all, although the social standards are also a form of social capital (confer Łopaciuk-Gonczaryk 2009, p. 37).

In evaluative approaches (normative), there are distinguished two types of social capital; with positive and negative effects. R. Putman (after: Golinowska 2009, p. 52; Łopaciuk-Gonczaryk 2009, pp. 39-40) introduced the division into the bonding social capital (bond), which unites within a given group, and the bridging social capital, which enables cooperation outside the group. Social capital of the bonding type may have negative consequences: the feeling of solidarity inside the given group can be based on «hostility» towards persons from outside. The integrating bonds may also «blind» that is hinder innovations and progress and the strong identification with the group poses a risk of locking and stagnation. While social capital of the bridging type allows for cooperation among social groups, helps overcoming inequalities and supporting tolerant conducts.

Research on social capital is conducted from the perspective of different scientific disciplines. Scientific achievements - especially in sociology - are significant, less so in the field of economy. The trans-disciplinary nature of social capital is borne out by the fact that it is related to numerous research currents, among other things, new institutional economy, social development theory, development economy, social economy, education sociology or theory of education or game theory. The rising interest in the problem of social capital when it comes to economic sciences is, first of all, a consequence of changes that occurred in the economy, in which knowledge is the basic economic 
resource. The result of the increase of relevance and updated concept of social capital is the proliferation of publications including many different approaches reflecting different research perspectives. Despite the increase of interest in social capital as such, this theory is still on the development stage (Skawińska 2012). Also S. Golinowska (2011, p. 1) notices that the literature regarding social capital, as well as empirical research conducted in the world do not contribute to the elimination of controversy regarding the cognitive and functional sense of this notion. Numerous authors have tried to find the proper definition and explanation for the term but this concept still remains, to a large extent, unclear. All authors agree that social capital is, first of all, capital, which means that when appropriately used, it multiplies and brings benefits, also in material sense. Social capital is not a category in itself, it exists in specific conditions (external and internal); the question remains, how the variety of constituent parts of social capital create common ground to share knowledge and generate innovation in Poland. During decades of theoretical discussions over this idea, its relevance changed and was significantly broadened. The research over social capital distinguishes over three perspectives of its description: micro, mezzo and macro (Grooaert, van Bastelaer 2001; Łopaciuk-Gonczaryk 2012, p. 8). On the micro level, an individual is examined from a point of view of individual advantages from participation in networks of social relations. On the meso-level, it is a group that is subjected to the analysis; social capital gains a character of collective good, from which the entire group profits. Social capital can also be examined at the macro level with reference to whole societies, which use it as a public good (Łopaciuk-Gonczaryk 2009, p. 38). In Poland, social capital research on the household level was conducted, among others, by M. Theiss (2012) and J.J. Sztaudynger (2009). On the local and regional level - C. Trutkowski, S. Mandes (2005), M. Herbst (2007), P. Swianiewicz (2008), K. Janc (2009), U. Markowska-Przybyła (2010), J. Działek (2011), E. Skawińska (2012). And on the national level - J.J. Sztaudynger (2005), J. Czapiński, T. Panek (2013). A glance at the available research reveals that initially the theory of social capital was developing in relation to local societies and communities (and influence of social networks on social welfare and the social macroeconomics of the country or the region), yet, gradually evolved into the organizational stage (enterprise). The enterprise is presently perceived as a source of social capital development. The development of social capital within an enterprise is visible through the increase of level of potential of its dimensions, e.g. increase of the level of trust in interpersonal contacts, striking a bigger number of close contacts with co-workers, or developing by the employees' new capabilities 
and competencies. Modern enterprises are no longer competing only through traditional, i.e. hard means of production, presently they concentrate also on intangible resources, among which, social capital is becoming an important source of value creation. Modern management of economic organizations puts growing emphasis on the ability to join, balance and adjust tangible and intangible assets, including broadening and developing social capital, relevant from the point of view of effective cooperation and realization of different economic goals. The ability to enterprises to create and broaden intellectual resources, including social capital, as well as appropriate relational and social links, has decisive relevance for generating unique competencies, especially precious for the maintenance of lasting competitive advantage. The conviction that, owing to its properties, it can generate competitive advantage through innovation.

\section{Social capital of an enterprise}

Social capital of the enterprise is a category resulting from the participation in networks of connections and relations, which are based on shared norms, principles and values as well as on confidence and enable the access to resources; in particular to knowledge and competences (Grzanka 2009, p. 88; Grzanka 2008, p. 83). D.R. Krause, R.B. Handfield and B.B. Tyler (after: Marcinkowska 2012, p. 20) indicate that it is aimed at generating specific benefits for the enterprise, such as: improving operational efficiency, increasing the development potential, gaining a competitive edge.

R. Leenders and S. Gabbay (after: Doryń 2010, p. 112) introduced the concept of social capital of the enterprise as a set of tangible and intangible (virtual) assets accessible through a network of social connections, which facilitate achieving intended objectives. It is in this approach, which is referred to as a structural one, that the network of interrelations is a sources of information above all (mainly public) for a specific participant in it. More recent studies widened the above concept by the dimension of the reciprocity of relationships within networks and the emphasis in the studies was moved on the analysis of processes of acquiring and sharing knowledge (both open and concealed), as well as mutual learning, which take place within networks.

The interest in the concept of social capital is a sign of the more and more universal recognition of its positive effect on shaping the competitive edge of enterprises and the increase in their market value. It is well known that only the business entities having a high level of social capital, thanks to the undisturbed 
flow of information, knowledge and experience are able to achieve the competitive edge. W. Baker (after: Bugdol 2006, p. 124) states that social capital is fundamental for the effectiveness of the enterprise, since it enhances the abilities to introduce innovations and is a kind of ", catalyst" for knowledge management. Better quality of social capital and its bigger amount support knowledge creation. Social capital provides access to knowledge as well as supports its utilization and creation (Nahapiet, Ghoshal 1998, s. 251).The enterprises having a high level of social capital are more willing to introduce new ways of operating in the market. Social capital helps also to reduce costs of the search for information. The access to information gained through relationships within a network reduces the costs of acquiring information (Zhou, Wu, Luo 2007, p. 679). Moreover, the information gained through a network of interrelationships is characterized by higher quality; it is more relevant and current compared with the information gained from other sources (Adler, Kwon 2002, p. 29).

The literature on the subject shows that the organizations having large amounts of social capital at their disposal are more willing to take a risk and implement new activities than the organizations, which put limits on the spontaneous creation of groups. It happens because social capital is a form of a social structure in the enterprise and strengthens the proactive behaviour of the people being inside this structure (Bratnicki 2001).

The social structure of the organization evolves by creation of new connections and relationships. In turn, new relationships modify the existing social capital creating chances for effective use of resources and their exchanges among individuals within the organization. It has to be also emphasized that a very important aspect of social capital in the modern economy is the creation of social bonds with customers, suppliers, recipients, investors, strategic partners and the like. In addition to the relationships inside the enterprise, which affect the improvement in the atmosphere at work or the increase in the effectiveness of teamwork, social capital enables fast flow of knowledge and cooperation amongst many external entities that allows increasing their adaptability, i.e. the ability to adopt to new requirements of the dynamically changing environment.

M. Marcinkowska (2012, pp. 20-21) distinguishes the internal and external social capital of the enterprise. The internal social capital is created by internal stakeholders and takes resources of the enterprise into account (and the resources of stakeholders - the employees and the management). The external social capital of the enterprise can be associated with the conducted activity, the widely comprehended environment or the market (figure 1). 


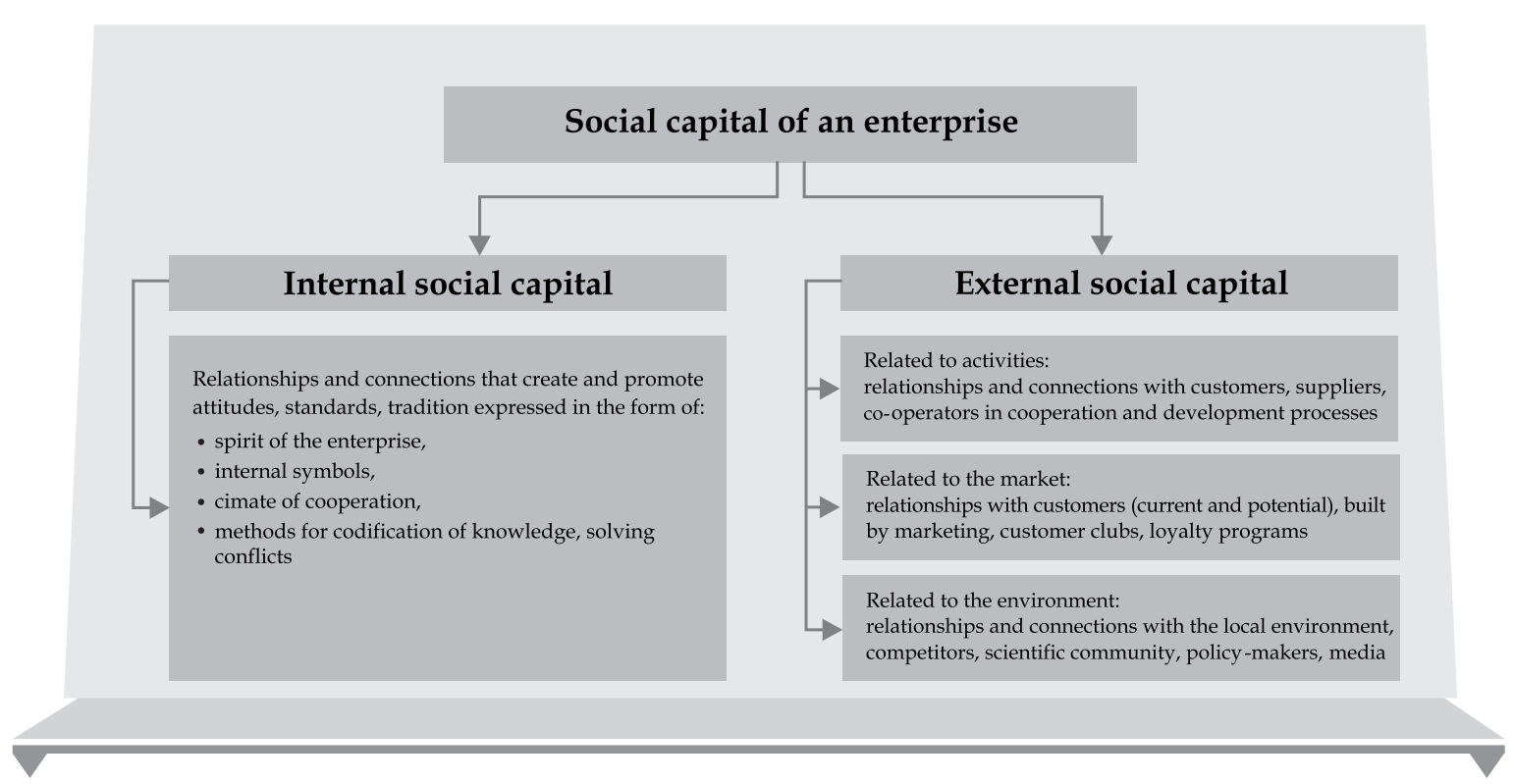

Figure 1. The components of social capital of the enterprise

Source: the diagram on the basis of Marcinkowska 2012, p. 20

The creation of social capital in order to gain the competitive edge requires (after: Marcinkowska 2012, p. 21): firstly - promotion of the development of communities of practitioners, including creation of unofficial groups of employees (within which they will share their knowledge and experience, solve problems together and the like) as well as of building the loyalty and the commitment of employees; secondly - gathering experience creating mutual trust among employees and supporting transparency in the working environment, in which there are no reasons for showing mistrusts and in which the rule is to trust employees; thirdly - promotion of the cooperation and partnership at all levels of the enterprise (as well as in relations with the environment); fourthly development of shared contexts of actions, understanding, language, symbols, standards, principles; and fifthly - applying the appropriate technology enabling creating and maintaining the network of relationships.

The theory of social capital of an enterprise is associated among others with J. Kay's (after: Jamka 2010, p. 25) concept of a success of a company based on abilities (i.e. resulting from the qualities, which miss in other companies, and are long-lasting and constitute the exclusive property of the company), which become a source of the competitive edge along with their application in the given sector and introduction on the market. However, the main measure of 
the success of the given enterprise is the value added, which is the appropriate incentive factor and the goal of the enterprise. J. Kay (after: Jamka 2010) lists three main distinguishing abilities: (1) architecture, constituting a network of internal contacts or contacts around the business, which takes three forms: of the internal architecture (relations with employees and between them), of the external architecture (relations with suppliers or customers) and of networks (relations within a group of companies dealing with related activities); the architecture enables an enterprise acquisition of organizational knowledge, determination of the conduct ways and the flexible response to changing circumstances, (2) the reputation, being the most important instrument for transmitting information for customers, that is the market way of solving a problem of the evaluation of these features of the product, which customers cannot check themselves easily, (3) innovation, for which J. Kay (after: Jamka 2010) emphasizes frequent assignment of the competitive edge, while in fact it is an effect of the distinguishing abilities, based on the architecture, aimed at the innovation itself, facilitating constant fast and effective introduction of next innovations or based on the exclusive ownership of the innovation, enabling the company quick and effective adapting generally available technologies.

The presented approach of J. Kay corresponds to the concept of social innovative capital of M.W. McElroy (after: Jamka 2010, pp. 26), according to which omitting social capital in discussions on the intellectual capital of the enterprise is tantamount to omitting its fundamental abilities to learn, to create innovations and adapt itself to market changes. According to M.W. McElroy (after: Jamka 2010, ss. 26-27), the third component of the intellectual capital (beside human and structural ones) is social capital in the form:

- of intra-social capital (of internal relationships), which is divided into the egocentric social capital (the value of individual relationships between individual persons/employees in the implementation process of objectives of the organisation) and sociocentric social capital (the value of the position of an individual in the structure of the organization, which is translated into an increase in opportunities to create the value added of the enterprise),

- of intersocial capital (of external relationships), being divided into the customer capital and partner capital,

- of social innovative capital, which is a "special, archetypal social pattern, which is aimed at creating, spreading and using the new knowledge in and for the organization", as well as a "set of independent leaners and communities of practical actions, which cooperate to organize ways of development and integration of the shared knowledge". 
The ability to create and to use the resources of social capital causes diversifying enterprises in terms of social capital maintained by them (Grzanka 2009, s. 89; Marcinkowska 2012, s. 21). Social capital being based on the ability of people to create connections and social relationships causes better use of human competences and knowledge. It is on this basis that it seems to be justified to consider social capital as a special component of the intellectual capital, which causes that human resources become a capital, i.e. they can be transformed into value creating the enterprise value (Grzanka 2009, s. 89). According to the concept of social capital, the relationships and connections of the people inside and among organizations constitute a potential - a social resource, which is capitalized in the enterprise as the increase in the value of the enterprise and the value delivered to customers as well as employees.

Enterprises enter into interactions with different entities (with stakeholders) - with customers, suppliers, competitors or also communities, create strategic alliances and networks, such as clusters, which serve combining the resources owned by enterprises and creating new knowledge. All these interactions are facilitated by social capital of the enterprise, which is reflected among others in the position of the enterprise in the network of connections, confidence level, shared standards - generally the level of the potential of individual dimensions of social capital.

The table 2 presents main characteristics of social capital: bonding and bridging and their impact on the efficiency of companies.

Table 2. Social capital of a corporation: bonding and bridging

\begin{tabular}{l|l|l}
\hline $\begin{array}{c}\text { Social capital of a corpo- } \\
\text { ration }\end{array}$ & \multicolumn{1}{c|}{ bonding } & \multicolumn{1}{c}{ bridging } \\
\hline Relationships & within a team & $\begin{array}{l}\text { amongst members of different } \\
\text { teams }\end{array}$ \\
\hline \multirow{2}{*}{ Indicators } & $\begin{array}{l}\text { good relationships amongst } \\
\text { members of one team } \\
\text { good relationships amongst } \\
\text { employees and supervisors } \\
\text { strong social standards (reci- } \\
\text { procity, loyalty) } \\
\text { team spirit” } \\
\text { identification }\end{array}$ & $\begin{array}{l}\text { number of relationships } \\
\text { diversity of relationships } \\
\text { hierarchy higher positions in the } \\
\text { gaps" }\end{array}$ \\
strength of relationships
\end{tabular}




\begin{tabular}{l|l|l} 
Methods of influence & $\begin{array}{l}\text { motivation, commitment, emo- } \\
\text { tional support }\end{array}$ & $\begin{array}{l}\text { access to information and assis- } \\
\text { tance, influence }\end{array}$ \\
\hline Impact on efficiency & $\begin{array}{l}\text { sharing knowledge, assistance } \\
\text { and communication within } \\
\text { a team, satisfaction of emplo- } \\
\text { yees, reduction of opportunism, } \\
\text { reduction of transaction costs } \\
\text { and rotation, speed and quality } \\
\text { of performing tasks requiring } \\
\text { co-operation in a team }\end{array}$ & $\begin{array}{l}\text { flow of information, innovations, } \\
\text { flow and creation of knowledge } \\
\text { in an organization, co-operation } \\
\text { amongst departments, speed and } \\
\text { quality of the tasks performed } \\
\text { requiring external assistance }\end{array}$ \\
\hline Weaknesses & $\begin{array}{l}\text { lack of flexibility, reduction in } \\
\text { innovations, lack of an element } \\
\text { of competition amongst em- } \\
\text { ployees }\end{array}$ & $\begin{array}{l}\text { the use of this capital to the benefit } \\
\text { of a company requires motivation }\end{array}$ \\
\hline
\end{tabular}

Source: study based on: Łopaciuk-Gonczaryk 2008, p. 47

In the literature, it is possible to find the opinions that traditional capitals, i.e. financial, material, as well as human capital, do not fully determine the process of the development of the enterprise, since they do not take social capital into account. Therefore, social capital is the missing element in the process of the economic development.

The importance of social capital in the context of the company development is presented, among others, in the studies using the network analysis (MolinaMorales, Martínez-Fernández 2010; Moran 2005; Oh, Chung, Labianca 2004; Sparrowe, Liden, Wayne, Kraimer 2001; Gargiulo, Benassi 2000), studies drawing attention to the role of the shared social standards and trust (Leana, Van Buren 1999; Nahapiet, Ghoshal 1998), as well as the literature on the subject of 'organizational citizenship behavior", which is equivalent to "civic involvement" at the company level (Bolino, Turnley, Bloodgood 2002; Koys 2001; Dyne, Graham, Dienesch 1994).

While basing on the literature analysis, it should be assumed that the quality of social capital in an enterprise can be determined with the use of the following components: participation in social structures (networks of interconnections and relationships), access to and use of resources (including knowledge and competences), shared social cooperation and interoperability standards as well as cultural standards, trust and common values.

The main reason for the interest of economists in social capital is its impact on efficiency. The importance of the social capital in the context 
of a company is mostly combined with the benefits, which can be obtained by the company with its use. The proper management of the social capital and care for its growth lead, among others, to stimulation of innovations and creativity, improvement of relationships with customers and suppliers, improvement of the company image and to a change of attitudes of employees that contributes to increase in efficiency and competitiveness of the business and its ongoing development.

\section{Summary}

The issues of social capital in economic science are present in the literature on the subject that justifies undertaking further studies and research. Despite the existence of many studies on social capital, particularly of purely theoretical character, there are many gaps in the research on social capital in Poland, whose filling up will contribute to better understanding of the concept of social capital on the level of an enterprise. A significant part of the available studies concerning social capital has purely descriptive character. The analyses are based primarily on quantitative data from surveys or on available secondary statistical data (Łopaciuk-Gonczaryk 2012). The random selection of the indicators is a deficit of the Polish research on social capital (based on the models derived from the western literature or on the criterion of the data availability). As evidenced by the literature, the concept of social capital and its reference to the enterprise has definitely preliminary character. The insufficiency of the results of empirical research inspires to completing the existing state of the knowledge in this field. Coping with this challenge seems to promise a specific cognitive value and may bring benefits associated with complementing knowledge within the scope of measurement of social capital and its impact on the development of enterprises

\section{Summary}

\section{Social capital of an enterprise}

The enterprise is presently perceived as a source of social capital development. The development of social capital within an enterprise is visible through the increase of level of potential of its dimensions, e.g. increase of the level of trust in interpersonal contacts, striking a bigger number of close contacts with coworkers, or developing by the employees' new capabilities and competencies. Modern enterprises are no longer competing only 
through traditional, i.e. hard means of production, presently they concentrate also on intangible resources, among which, social capital is becoming an important source of value creation. Modern management of economic organizations puts growing emphasis on the ability to join, balance and adjust tangible and intangible assets, including broadening and developing social capital, relevant from the point of view of effective cooperation and realization of different economic goals. The ability to enterprises to create and broaden intellectual resources, including social capital, as well as appropriate relational and social links, has decisive relevance for generating unique competencies, especially precious for the maintenance of lasting competitive advantage.

It is in this article that the key issues of social capital in enterprises are presented with the use of a critical review of the literature on this subject. It is a new and simultaneously very topical issue that is reflected in numerous theoretical and empirical studies published in the world literature over the last years. The aim of this article is to present the concept of social capital by taking into account the influence of this capital on functioning of an enterprise.

Keywords: $\quad$ social capital, enterprise, intangible assets.

\section{Streszczenie}

\section{Kapitał społeczny przedsiębiorstwa}

Przedsiębiorstwo jest obecnie postrzegane jako źródło rozwoju kapitału społecznego. Rozwój kapitału społecznego $\mathrm{w}$ przedsiębiorstwie przejawia się zwiększeniem poziomu potencjału jego wymiarów, np. wzrostem poziomu zaufania w kontaktach międzyludzkich, nawiązaniem większej ilości bliskich kontaktów ze współpracownikami, czy też rozwinięciem przez pracowników nowych zdolności i kompetencji. Współczesne przedsiębiorstwa przestają konkurować wyłącznie za pomocą tradycyjnych, tzw. twardych czynników produkcji, koncentrując swoją uwagę także na zasobach niematerialnych, wśród których ważnym źródłem kreacji wartości staje się kapitał społeczny. We współczesnym zarządzaniu organizacjami gospodarczymi coraz większą wagę przypisuje się do umiejętności łączenia, równoważenia 
i dostosowania zasobów materialnych $\mathrm{z}$ niematerialnymi, w tym poszerzania i rozwoju kapitału społecznego, istotnego z punktu widzenia efektywnego współdziałania oraz realizacji różnych celów ekonomicznych. Zdolność przedsiębiorstw do tworzenia i poszerzania zasobów intelektualnych, w tym kapitału społecznego, a także odpowiednich relacji i powiązań społecznych, ma decydujące znaczenie dla tworzenia unikatowych kompetencji, szczególnie cennych dla utrzymania trwałej przewagi konkurencyjnej.

W artykule, wykorzystując krytyczną analizę literatury przedmiotu, przedstawiono kluczowe zagadnienia kapitału społecznego przedsiębiorstwa. Jest to zagadnienie nowe i jednocześnie aktualne, czego wyrazem są liczne w literaturze światowej $\mathrm{W}$ ostatnich latach opracowania teoretyczne i empiryczne. Celem artykułu jest zaprezentowanie koncepcji kapitału społecznego, uwzględniając wpływ tego kapitału na funkcjonowanie przedsiębiorstwa.

\section{Słowa}

kluczowe: kapitat społeczny, przedsiębiorstwo, wartości niematerialne.

\section{References:}

1. Adamczyk M. (2013), Wprowadzenie do teorii kapitału społecznego, Wyd. KUL, Lublin.

2. Adler P. S., Kwon S.(2002), Social Capital: Prospects for a New Concept, "Academy of Management Review", Vol. 27, No. 1.

3. Będzik B. (2012), Kapitat społeczny a gospodarka oparta na wiedzy, Folia Pomeranae Universitatis Technologiae Stetinesis, Oeconomica, nr 292 (66), Szczecin.

4. Bolino M. C., Turnley W. H., Bloodgood J. M. (2002), Citizenship Behavior and the Creation Of Social Capital in Organizations, "Academy of Management Review", Vol. 27, No. 4.

5. Boni M. (red.) (2009), Polska 2030. Wyzwania rozwojowe, Kancelaria Prezesa Rady Ministrów, Warszawa.

6. Bordieu P. (1985), The Forms of Capital, in: Handbook of Theory and Research for the Sociology of Education, J.G. Richardson (ed.), Greenwood Press, New York.

7. Bratnicki M. (2001), Dylematy i pułapki wspótczesnego zarządzania, Polska Akademia Nauk. Oddział w Katowicach. Komisja Nauk Organizacji i Zarządzania, Katowice. 
8. Buchanan J. M. (2001), Game theory, mathematics, and economics, "Journal of Economic Methodology", vol. 8, no 1.

9. Bugdol M. (2006), Wartości organizacyjne. Szkice z teorii organizacji i zarzadzania, Wydawnictwo Uniwersytetu Jagiellońskiego, Kraków.

10. Coleman J. (1990), Foundation of Social Theory, The Belknap Press of Harvard University Press, Cambridge, Massachusetts, London.

11. Czapiński J., Panek T. (2013), Diagnoza społeczna 2013: warunki i jakość życia Polaków, Zakład Wydawnictw Statystycznych, Warszawa.

12. Doryń W. (2010), Wptyw kapitału społecznego na internacjonalizacje przedsiębiorstw, "Gospodarka Narodowa”, nr 11-12.

13. Dyne L. V., Graham J. W., Dienesch R. M. (1994), Organizational Citizenship Behavior: Construct Redefinition, Measurement, and Validation, "Academy of Management Journal", Vol. 37, No. 4.

14. Działek J. (2011), Kapitał społeczny jako czynnik rozwoju gospodarczego w skali regionalnej i lokalnej w Polsce, Wydawnictwo Uniwersytetu Jagiellońskiego, Kraków.

15. Fazlagić A. (2005), Problematyka budowy kapitatu społecznego w Polsce, Zeszyty Naukowe Wyższej Szkoły Handlu i Usług w Poznaniu, nr 8, Poznań.

16. Fukuyama F. (1995), Trust: The Social Virtues and the Creation of Prosperity, Free Press Paperbacks, New York.

17. Fukuyama F. (1997), Social Capital, The Tanner Lectures on Human Values, Brasenose College, Oxford.

18. Fukuyama F. (2001), Social capital, civil society and development, "Third World Quarterly", Vol 22, No 1.

19. Gajowiak M. (2012), Kapitał społeczny. Przypadek Polski, PWN, Warszawa.

20. Gargiulo M., Benassi M. (2000), Trapped in Your Own Net? Network Cohesion, Structural Holes, and the Adaptation of Social Capital, "Organization Science" Vol. 11, No. 2.

21. Golinowska S. (2009), Więzi społeczne i kapitat społeczny we wspótczesnej Polsce. Porównanie z innymi krajami Unii Europejskiej, w: S. Golinowska, J. Wilkin, M. Bednarski, U. Sztanderska, M. W. Socha, B. BalcerzakParadowska (red.), Więzi społeczne i przemiany gospodarcze. Polska i inne kraje europejskie, Instytut Pracy i Spraw Socjalnych, Warszawa.

22. Golinowska S. (2011), O spójności i kapitale społecznym oraz europejskiej i polskiej polityce spójności, „Polityka Społeczna”, nr 5-6.

23. Grooaert C., van Bastelaer T. (2001), Understanding and Measuring Social Capital: a Synthesis of Findings and Recommendations from the Social Capital Initiative, Social Capital Initiative Working Paper, no. 24, World Bank, Washington.

24. Grzanka I. (2008), Badania nad wykorzystywaniem kapitału społecznego przedsiębiorstwa w kształtowaniu relacji $z$ klientami $w$ przedsiębiorstwach 
teleinformatycznych w Polsce, „Kwartalnik Naukowy Organizacja i Zarządzanie Politechnika Śląska" nr 4, Gliwice.

25. Grzanka I. (2009), Kapitał społeczny w relacjach z klientami. CRM a społeczny potencjat przedsiębiorstwa, Wydawnictwo CeDeWu, Warszawa.

26. Hausner J. (2010), Za dużo kapitalizmu, za mało kapitału... społecznego, w: K. Gołata (red.), Bohaterowie polskiej transformacji, Wydawnictwo W.A.B, Warszawa.

27. Herbst M. (red.) (2007), Kapitat ludzki i kapitał społeczny a rozwój regionalny, PWN, Warszawa.

28. Jamka B. (2010), Redefinicja celu wspótczesnego przedsiębiorstwa wobec koncepcji zrównoważonego rozwoju i kapitału społecznego, „Organizacja i Kierowanie", nr 3 (141).

29. Janc K. (2009), Zróżnicowanie przestrzenne kapitału ludzkiego i społecznego $w$ Polsce, Instytut Geografii i Rozwoju Regionalnego Uniwersytetu Wrocławskiego, Rozprawy Naukowe Instytutu Geografii i Rozwoju Regionalnego Uniwersytetu Wrocławskiego, nr 8, Wrocław.

30. Jaźwiński I. (2010), Kapitał społeczny w gospodarce opartej na wiedzy, Zeszyty Naukowe Uniwersytetu Szczecińskiego, nr 589 Ekonomiczne Problemy Usług nr 57, Szczecin.

31. Klimowicz M., Bokajło W. (2010), Kapitat społeczny - interpretacje, impresje, operacjonalizacja, Wydawnictwo CeDeWu, Warszawa.

32. Knack S., Keefer P. (1997), Does Social Capital have an economic payoff? A cross-country investigation, "Quarterly Journal of Economics" Vol. 112, Issue 4.

33. Koys D. J. (2001), The Effects of Employee Satisfaction, Organizational Citizenship Behavior, and Turnover on Organizational Effectiveness: A Unit-Level, Longitudinal Study, „Personnel Psychology”, Vol. 54, Issue 1.

34. Leana C. R., Van Buren III H. J. (1999), Organizational Social Capital And Employment Practices, "Academy of Management Review”, Vol. 24, No. 3.

35. Łopaciuk-Gonczaryk B. (2008), Oddziaływanie kapitatu społecznego korporacji na efektywność pracowników, „Gospodarka Narodowa”, nr 1-2.

36. Łopaciuk-Gonczaryk B. (2009), Więzi społeczne, zaufanie $i$ kapitał społeczny, w: S. Golinowska, J. Wilkin, M. Bednarski, U. Sztanderska, M. W. Socha, B. Balcerzak-Paradowska (red.), Więzi społeczne i przemiany gospodarcze. Polska i inne kraje europejskie, Instytut Pracy i Spraw Socjalnych, Warszawa.

37. Łopaciuk-Gonczaryk B. (2012), Mierzenie kapitału społecznego, „Gospodarka Narodowa", nr 1-2.

38. Marcinkowska M. (2012), Kapitał społeczny przedsiębiorstwa - próba syntezy literatury przedmiotu, „Przegląd Organizacji”, nr 10.

39. Markowska-Przybyła U. (2010), Kapitat społeczny jako czynnik rozwoju regionalnego, w: W. Kosiedowski (red.), Kapitał ludzki w procesie przemian Europy Środkowej i Wschodniej, Dom Organizatora TNOiK, Torun. 
40. Matysiak A. (2011), Społeczny kapitał rynkowy, „Polityka Społeczna”, nr $5 / 6$.

41. Ministerstwo Gospodarki (2013), Strategii Innowacyjności i Efektywności Gospodarki. Dynamiczna Polska 2020, Warszawa.

42. Molina-Morales F. X., Martínez-Fernández M. T. (2010), Social Networks: Effects of Social Capital on Firm Innovation, "Journal of Small Business Management", 48(2).

43. Moran P. (2005), Structural vs. Relational Embeddedness: Social Capital and Managerial Performance, "Strategic Management Journal”, Vol. 26, No. 12.

44. Mularska-Kucharek M. (2012), Kapitat społeczny a postawy $i$ działania przedsiębiorcze mieszkańców Łodzi, Wydawnictwo Uniwersytetu Łódzkiego, Łódź.

45. Nahapiet J., Ghoshal S. (1998), Social Capital, Intellectual Capital, and the Organizational Advantage, "Academy of Management Review”, Vol. 23, No. 2.

46. Oh H., Chung M., Labianca G. (2004), Group Social Capital and Group Effectiveness: The Role of Informal Socializing Ties, "AAcademy of Management Journal", Vol. 47, No. 6.

47. Polska 2030. Wyzwania rozwojowe (2009), Kancelaria Prezesa Rady Ministrów, Warszawa.

48. Portes, A. (1998), Social Capital: Its Origins and Application in Modern Sociology, „Annual Review of Sociology”, 24.

49. Putnam, R. D. (1995), Bowling Alone: America's Declining Social Capital, "Journal of Democracy", Vol. 6, No. 1, January.

50. Siwiński W. (2005), Międzynarodowe zróżnicowanie rozwoju gospodarczego: fakty i teoria, "Ekonomista”, nr 6.

51. Skawińska E. (red.) (2012), Kapitat społeczny w rozwoju regionu, PWN, Warszawa.

52. Sławecki B. (2011), Zatrudnienie po znajomości. Kapitał społeczny na rynku pracy, Wydawnictwo C.H. Beck, Warszawa.

53. Sparrowe R. T., Liden R. C., Wayne S. J., Kraimer M. L. (2001), Social Networks and the Performance of Individuals and Groups, "Academy of Management Journal", Vol. 44, No. 2.

54. Swianiewicz P. (2008), Szafarze darów europejskich: kapitał społeczny a realizacja polityki regionalnej w polskich województwach, Scholar Warszawa.

55. Sztaudynger J. J. (2005), Wzrost gospodarczy a kapitał społeczny, prywatyzacja i inflacja, PWN, Warszawa.

56. Sztaudynger J. J. (2009), Rodzinny kapitat społeczny a wzrost gospodarczy w Polsce, Annales. Etyka w Życiu Gospodarczym, T. 12, nr 1, Łódź.

57. Theiss M. (2012), Krewni, znajomi, obywatele: kapitat społeczny a lokalna polityka społeczna, Wydawnictwo Adam Marszałek, Torun.

58. Trutkowski C., Mandes S. (2005), Kapitat społeczny w matych miastach, Wydawnictwo Naukowe Scholar, Warszawa. 


\section{Management \\ 2014}

Vol.18, No. 1

59. Wilczyński W. (2009), Dylematy polityki ustrojowej, w: E. Mączyńska (red.), Polska transformacja i jej przyszłość, VIII Kongres Ekonomistów Polskich, Polskie Towarzystwo Ekonomiczne, Warszawa.

60. Woolcock, M. (1998), Social capital and economic development: Toward a theoretical synthesis and policy framework, "Theory and Society", 27.

61. Zhou L., Wu W., Luo X. (2007), Internationalization and the performance of born-global SMEs: the mediating role of social networks, "Journal of International Business Studies", Vol. 38.

62. Żołnierski A. (2011), Kapitat społeczny w polskich przedsiębiorstwach, „Ekonomika i Organizacja Przedsiębiorstwa”, nr 9. 